УДК 378.09:796+378.147

DOI:

Лариса Волошко, кандидат педагогічних наук, доцент кафедри фізичного виховання, спорту та здоров'я людини Полтавського національного технічного університету імені Юрія Кондратюка

\title{
ЗАСТОСУВАННЯ ФРЕЙМОВИХ ТЕХНОЛОГІЙ У ПРОЦЕСІ МЕДИКО- БІОЛОГІЧНОӤ ПІДГОТОВКИ МАЙБУТНІХ ФІЗИЧНИХ ТЕРАПЕВТІВ
}

У статті проаналізовано результати педагогічного експерименту щуодо оцінки ефективності використання фреймових технологій в прочесі вивчення майбутніми фізичними терапевтами медикобіологічних дисичплін. Фрейми, як дидактичні засоби, охарактеризовано з позицій пізнавально-змістовного та організаційно-методичного аспектів; розкрито методику їх застосування у прочесі вивчення медикобіологічних дисциплін. Підтверджено, щзо застосування фреймових технологій дає можливість об 'єктивно підвищчити рівень засвоєння знань студентів спеціальності “Фізична терапія, ерготерапія”, їх міичність та довготривалість.

Ключові слова: майбутні фізичні терапевти; фреймові технологї̈; фрейм; інтелект-карти; структурування.

Табл. 1. Лім. 5.

Larysa Voloshko, Ph. D.(Pedagogy), Assosiate Professor of Physical Education, Sport and Human Health Department, Poltava Yuriy Kondratyuk National Technical University

\section{USE OF FRAME TECHNOLOGIES IN THE PROCESS OF MEDICALAND BIOLOGICAL PREPARATION OFTHE FUTURE PHYSICALTHERAPISTS}

The purpose of the study was to substantiate the didactic capabilities and to evaluate the effectiveness of the use of frame technologies in the process of studying of the future physical therapists of medical and biological disciplines. The study was attended by 1-4 year students of the humanities faculty 227 "Physical rehabilitation / Physical therapy, ergotherapy" specialty from Poltava Yuriy Kondratyuk National Technical University. The author used the research methods: theoretical, pedagogical, and statistical. The frames, as means of didactics, are characterized from the standpoint of cognitive-content and organizational-methodical aspects; the method of their application in the process of studying the medical and biological disciplines, including the use of structural-logical schemes, educational thesauruses, compact textbooks, mind maps, is disclosed.

The development of framing structures involves the following levels of systematization of educational information: 1) the allocation of key concepts; 2) the selection of the essential features of these concepts; 3) comparative comparison of the features of different concepts under study; 4) the establishment of the hierarchy of concepts under study; 5) sign-content "condensation" of the educational material - the transfer of information into a graphic-symbolic, structured form.

In our opinion, the main properties of the frame structures are: 1) didactic operational - the obligatory allocation of the basic elements of knowledge, determination of logical interrelations between them at the expense of horizontal (intra-disciplinary) and vertical (interdisciplinary) integration; 2) systematic - focusing on the development of holistic representations of the object or process being studied; 3) invariance-inclusion in the frame structures of not only subject knowledge, but also components of knowledge of logical and methodological nature, which allows students to develop the skills of invariant transfer of knowledge and skills in new conditions; 4) ergonomics - increasing the informative capacity of the content of the educational material, assimilating a greater amount of knowledge per unit time; 5) profitability - increase the efficiency of processing the training information, reducing the time for searching and reproduction of educational material.

It is confirmed that the application of frame technologies makes it possible to objectively increase the level of mastering the knowledge of the students of 227 "Physical therapy, ergotherapy" specialty, their strength and durability.

Keywords: the future physical therapists; frame technologies; frame; mind maps; structuring.

П остановка проблеми. У 2015 році Постанова Кабінету Міністрів України № 266 затвердила підготовку здобувачів вищої освіти за спеціальністю 227 "Фізична терапія, ерготерапія” галузі знань 22 “Охорона здоров'я”.
У 2017 році до Національного класифікатора України "Класифікатор професій ДК003 2010" було внесено професійні назви роботи “фізичний терапевт" та "ерготерапевт". Наказом МО3 України № 2331 від 13.12.2018р. внесено зміни 
до кваліфікаційної характеристики фізичного терапевта, ерготерапевта, асистента фізичного терапевта, ерготерапевта. Отже, активний розвиток реабілітаційного напрямку, зміни нормативно-правової бази діяльності стали поштовхом для перегляду та затвердження нових освітньо-професійних програм підготовки бакалаврів і магістрів спеціальності 227 “Фізична терапія, ерготерапія".

Однак, модернізація нормативної бази не вирішила всіх нагальних проблем підготовки цих фахівців у закладах вищої освіти. Реаліями професійної підготовки майбутніх фізичних терапевтів $є$ значна кількість передбачених навчальними планами дисциплін, перевантаженість студентів інформацією, що в більшості випадків $€$ візуально недостатньо репрезентованою, недосконалість структурно-логічних схем викладання обов'язкових і вибіркових курсів, неузгодженість міждисциплінарних зв'язків.

У цьому зв'язку актуалізується проблема розробки та впровадження новітніх технологій навчання з метою підвищення якості знань, умінь і навичок майбутніх фізичних терапевтів, розвитку їхнього гнучкого професійного мислення 3 урахуванням рекомендацій World Confederation for Physical Therapy. У даному контексті значні дидактичні можливості, на нашу думку, мають фреймові технології навчання, що базуються на концепції фрейма як особливої когнітивної структури.

Аналіз останніх досліджень і публікацій. Термін “фреймова технологія” запозичений 3 теорії системного викладу знань американського дослідника Мервіна Мінського. Ми поділяємо думку М. Мінського в тому, що людина пізнає та засвоює нові знання на основі відтворення в пам'яті вже знайомої, певної структури даних (відомостей). Будь-який змістовний фрейм складається зі слотів - одиниць зберігання знання (інформації). Кількість слотів у фреймі може бути різною. Слот має стандартну структуру: ім'я та сукупність конкретних атрибутів. Слот може нести конкретне значення, або виступати функцією, що передбачає подальшу дивергентну деталізацією інформації, а також містити посилання на інший слот або фрейм. Ланцюг фреймових структур нижчих рівнів ієрархії формує фрейм вищого рівня [3]. Отже, слотова декомпозиція різнорівневих фреймів відображує їх ієрархічну взаємозалежність і взаємопов'язаність.

Фреймові підходи у навчанні досліджувалися в роботах I. Андрощук, Л.В. Дольникової, T.М. Колодочки, В. Штейнберга т.ін., але методичні умови їх впровадження в процесі медико-біологічної підготовки фізичних терапевтів ще не був предметом спеціального дослідження.

Мета дослідження: обгрунтувати дидактичні можливості та оцінити ефективність використання фреймових технологій в процесі вивчення майбутніми фізичними терапевтами медикобіологічних дисциплін.

Методи й організація дослідження. Під час дослідження використано: теоретичні методи (аналіз та узагальнення даних науково-методичної літератури), педагогічні методи (педагогічний експеримент, тестування), методи математичної статистики. Експериментальна перевірка ефективності застосування фреймових технологій здійснювалася протягом 2016 - 2018 років у ході паралельного педагогічного експерименту, в якому брали участь 145 студентів 1 - 4 курсів гуманітарного факультету спеціальності 227 “Фізична реабілітація / Фізична терапія, ерготерапія" Полтавського національного технічного університету імені Юрія Кондратюка (Україна).

Виклад основного матеріалу. Важливою складовою фахової підготовки майбугніх фізичних терапевтів виступають медико-біологічні дисципліни (“Анатомія людини”, “Біологія людини”, “Фізіологія людини, “Основи патологіі”, “Загальна теорія здоров’я” та ін.); саме їх зміст формує фундаментальне підгрунтя для вивчення професійно орієнтованих дисциплін. У процесі викладання медико-біологічних дисциплін ми застосовуємо фреймові технології. Найбільш ефективними способами застосування фреймів, як дидактичних засобів, на нашу думку, є:

- побудова інтегративних структурно-логічних схем (графів) із візуалізацією навчального матеріалу;

- формування навчальних тезаурусів, що містять поняття різних рівнів та дозволяють відтворити їх ієрархічну класифікацію;

- застосування проблемно-ситуаційних завдань на основі прийому “згортання-розгортання" навчальної інформації;

- розробка е-версій фреймових опор у форматі структурованих компакт-підручників;

- використання mind-maps (ментальних карт) 3 представленням інформації в графічному вигляді, що відображає зв'язки між поняттями (змістові, асоціативні, причинно-наслідкові) [1], у тому числі 3 використанням безкоштовних комп'ютерних програм, які можна 3 легкістю використовувати дистанційно.

Фрейм, як дидактичний засіб, ми розглядаємо з позицій двох аспектів: 1) фрейм як інформаційний масив, що характеризується конкретним 


\section{ЗАСТОСУВАННЯФРЕЙМОВИХ ТЕХНОЛОГЙ У ПРОЦЕСІ МЕДИКО-БІОЛОГІЧНӦ̈ ПІГОТОВКИ МАЙБУТНІХ ФІЗИЧНИХ ТЕРАПЕВТІВ}

способом структурування та інтегрування навчальної інформації (пізнавально-змістовний аспект); 2) фрейм як алгоритм послідовності вивчення навчального матеріалу (організаційнометодичний аспект) [2].

Пізнавально-змістовний аспект. Поділяючи думку науковців, що знання носять структурований характер, у своїх поглядах щодо впровадження фреймових технологій навчання дотримуємося системного підходу, що вимагає розгляду різноякісних елементів знань 3 урахуванням їх походження, структури та взаємозв'язків між ними.

Вважаємо, що професійно орієнтовані елементи знань повинні бути інтегрованими, оскільки їх фрагментарність не може забезпечити формування цілісної системи фахової компетентності майбутніх фахівців. Набуті знання не набудуть статусу інтегрованих, якщо вони вивчаються окремо, без урахування зв'язків між ними. На нашу думку, структурування навчального матеріалу 3 використанням фреймових структур забезпечує високий рівень систематизації знань студентів. У цьому зв'язку фрейм - це каркасна структура для запам'ятовування навчальної інформації студентами, лаконічної фіксації її найбільш значущих моментів із метою їх подальшого відтворення. В основі фреймових технологій лежить логізація складних процесів та явищ, що вивчаються студентами [4]. Фрейм вищого рівня, інформація про атрибути якого використовується у фреймах нижчих рівнів, ми характеризуємо як базисний: базисний фрейм $\rightarrow$ фрейм j-рівня, де j - номер рівня.

Організаційно-методичний аспект. Якщо послідовність вивчення слотів одного фрейма співпадає з послідовністю вивчення відповідних слотів інших фреймів, то засвоєння наступних фреймів потребує менших часових витрат. Вивільнений бюджет часу повинен бути використаний для розвитку самостійності студентів шляхом збільшення частки завдань творчо-пошукового характеру.

Розробка фреймових структур передбачає наступні рівні систематизації навчальної інформації: 1) виділення ключових понять; 2) виділення сутнісних ознак цих понять; 3 ) порівняльне співставлення ознак різних понять, що вивчаються; 4) встановлення ієрархії понять, що вивчаються; 5) знаково-змістовне “згущення" навчального матеріалу - перевід інформації в графічно-символічну, структуровану форму.

Основними властивостями фреймових структур, на нашу думку, є: 1) дидактична операційність - обов'язковість виділення базових елементів знань, визначення логічних взаємозв' язків між ними за рахунок горизонтальної (внутрішньодисциплінарної) та вертикальної (міждисциплінарної) інтеграції; 2) системність орієнтація на розвиток цілісних уявлень про об'єкт чи процес, що вивчаються; 3) інваріантість включення у фреймові структури не лише предметних знань, а й компонентів знань логікометодологічного характеру, що дозволяє сформувати у студентів навички інваріантного переносу знань і умінь у нові умови; 4) ергономічність - підвищення інформативної ємкості змісту навчального матеріалу, засвоєння в одиницю часу більшого обсягу знань; 5) економічність - збільшення ефективності опрацювання навчальної інформації, скорочення часу для пошуку та відтворення навчального матеріалу.

Для оцінки рівня засвоєння знань студентів 3 використанням фреймових технологій необхідно враховувати рекомендовану 6-рівневу таксономію навчальних цілей і результатів Б. Блума (запом'ятовування - розуміння - застосування аналіз - синтез - оцінка) [5].

Застосування фреймових технологій у процесі вивчення медико-біологічних дисциплін забезпечує підвищення рівня засвоєння знань студентів спеціальності 227 “Фізична терапія, ерготерапія”, їх міцність та довготривалість (табл. 1).

Аналіз емпіричних даних за критерієм Фішера показав, що з достовірною ймовірністю 0,95 ( $\varphi_{\text {емп }}$ $\left.>\varphi_{\text {кр.0,05 }}, \varphi_{\text {кр. } 0,05}=1,64\right)$ значення коефіцієнтів засвоєння та міцності знань студентів експериментальної та контрольної груп статистично відрізняються. В експериментальній групі коефіцієнт засвоєння знань $\left(\mathrm{K}_{\alpha}\right)$ зріс на 48,9 $\%$ - з 0,415 до 0,812 ( $\left.\varphi_{\text {емп }}=5,24\right)$, відсоток студентів 3 оптимальним значенням коефіцієнта засвоєння професійних знань $\left(\mathrm{K}_{\alpha}>0,7\right)$ збільшився у 2,18 рази - з 35,4\% до 77,2 \% ( $\left.\varphi_{\text {емп }}=5,41\right)$, коефіцієнт міцності знань $\left(\mathrm{K}_{\mathrm{M}}\right)$ зріс на $27,4 \%-3$ 0,469 до 0,646 ( $\left.\varphi_{\text {емп }}=2,22\right)$.

У контрольній групі коефіцієнт засвоєння знань $\left(\mathrm{K}_{\alpha}\right)$ зріс на $14,08 \%$ - 3 0,424 до 0,497 , що достовірно менше ніж в експериментальній групі $\left(\varphi_{\text {емп }}<\varphi_{\text {кр. } 0,05} ; \varphi_{\text {емп }}=0,91 ; \varphi_{\text {кр.0,05 }}=1,64\right)$. Кількість студентів 3 оптимальним значенням $\mathrm{K}_{\alpha}$ збільшилась лише в 1,3 рази - 3 37,3 \% до 49,3 \% $\left(\varphi_{\text {емп }}=1,51\right)$. Коефіцієнт міцності знань (Км) змінився недостовірно з 0,489 до $0,513\left(\varphi_{\text {емп }}=\right.$ 0,29).

Висновки. Застосування фреймових технологій у навчанні медико-біологічних 
Таблиця 1.

Динаміка засвосння та міцності знань студентів спеціальності “Фізична реабілітація/ Фізична терапія, ерготерапія" за час експерименту

\begin{tabular}{|c|c|c|c|c|c|c|c|c|c|c|}
\hline \multirow[t]{2}{*}{ Показник } & \multicolumn{5}{|c|}{ Експериментальна група } & \multicolumn{5}{|c|}{ Контрольна група } \\
\hline & 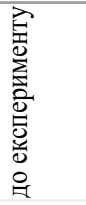 & 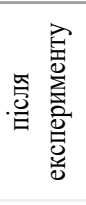 & 言 & 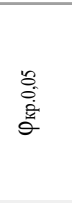 & . & 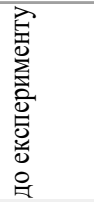 & 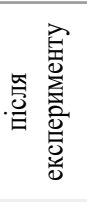 & 言 & 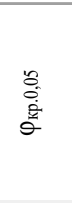 & 蔓 \\
\hline $\begin{array}{c}\mathrm{K}_{\alpha} \\
\text { (середнє } \\
\text { значення) }\end{array}$ & 0,415 & 0,812 & 5,24 & \multirow[t]{3}{*}{1,64} & \multirow{3}{*}{ 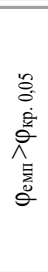 } & 0,424 & 0,497 & 0,91 & \multirow[t]{3}{*}{1,64} & \multirow{3}{*}{ 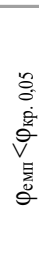 } \\
\hline $\begin{array}{c}\text { Відсоток } \\
\text { студентів } 3 \\
\mathrm{~K}_{\alpha}>0,7\end{array}$ & 35,4 & 77,2 & 5,41 & & & 37,3 & 49,3 & 1,51 & & \\
\hline $\begin{array}{c}\mathrm{K}_{\mathrm{M}}(\text { середнє } \\
\text { значення })\end{array}$ & 0,469 & 0,646 & 2,22 & & & 0,489 & 0,513 & 0,29 & & \\
\hline
\end{tabular}

дисциплін є ефективним засобом формування системного мислення, генералізації знань майбутніх фізичних терапевтів та інтенсифікації освітнього процесу. Якісний і кількісний аналіз результатів проведеного педагогічного експерименту підтвердив зростання коефіцієнтів засвоєння й міцності знань здобувачів вищої освіти спеціальності 227 “Фізична терапія, ерготерапія”, що свідчить про ефективність фреймових технологій навчання у порівнянні з традиційними.

Подальші напрями досліджень необхідно спрямувати на розробку фреймових структур, як дидактичних засобів навчання медико-біологічних дисциплін, із застосуванням комп'ютерних програм.

\section{ЛІТЕРАТУРА}

1. Бьюзен Т., Бьюзен Б. Интеллект-карты. Практическое руководство. Москва, 2010. 352 с.

2. Волошко Л. Б. Фреймові технології у навчанні студентів ВНЗ. Педагогіка, психологія та медико-біологічні проблеми фізичного виховання і спорту. 2006. С. 31-3.

3. Минский М. Фреймы для представления знаний. Москва, 1979. - 151 с.

4. Медведенко Н. В. Фрейм как базовое понятие педагогических технологий. Сибирский пед. Журнал [Інтернет]. 2011 Лист [цитовано 2019 Січ 30];C.102-7. URL: https://cyberleninka.ru/article/ $\underline{\text { n/freym-kak-bazovoe-ponyatie-pedagogicheskih- }}$ tehnologiy

5. Bloom B. S. Taxonomy of educational objectives: The classification of educational goals. New York: Longman; 1994. 112 p.

\section{REFERENCES}

1. Byuzen, T. \& Byuzen, B. (2010). Intellektkartyi. Prakticheskoe rukovodstvo [Intellect card. Practical guide]. Moskov, 352 p. [in Russian].

2. Voloshko, L. B. (2006). Freimovi tekhnolohii u navchanni studentiv VNZ [Frame technology in the teaching of university students]. Pedagogy, Psychology and the medical and biological problems of physical education and sports. pp.313. [in Ukrainian].

3. Minskiy, M. (1979). Freymy dlya predstavleniya znaniy [Frames for representation of knowledge]. Moskov, 151 p. [in Russian].

4. Medvedenko, N.V. (2011). Freym kak bazovoye ponyatiye pedagogicheskikh tekhnologiy [Frame as a basic concept of educational technology]. Siberian Pedagogical Journal. (Accessed 30 January 2019). pp. 102-7. Available at: https://cyberleninka.ru/article/ n/freym-kak-bazovoe-ponyatie-pedagogicheskihtehnologiy [in Russian].

5. Bloom, B. S. (1994). Taxonomy of educational objectives: The classification of educational goals. New York: Longman, 112 p. [in English].

Стаття надійшла до редакції 19.02.2019

\section{G580s}

“Розум полягає не лише у знанні, але й у вмінні застосовувати ці знання".

Apicmoтель

давньогрецький вчений

\section{}

